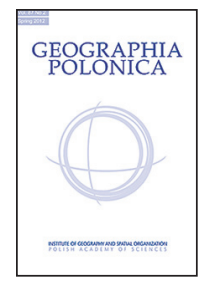

\title{
QUARRIES IN LANDSCAPE AND GEOTOURISM
}

\section{Jerzy Nita}

\author{
University of Silesia \\ Faculty of Earth Sciences \\ Będzińska 60, 41-200 Sosnowiec: Poland \\ e-mail address: jerzy.nita@us.edu.pl
}

\begin{abstract}
In Poland there are about 590 actively quarried deposits of mineral resources referred to as natural building stone, or quarry stone (database Midas). According to data from the Polish Geological Institute 730 medium and large quarries are located throughout the country. Most of the quarries work sandstone, limestone, granite, basalt or dolomite. The largest Polish sites exceed $1 \mathrm{~km}^{2}$ in area, while those in other countries can be larger than $10 \mathrm{~km}^{2}$. Once its mineral working operations cease, a quarry begins functioning in harmony with the landscape as a former mineral working site. That is when the biotic and abiotic elements arrive at a state of equilibrium. The scenic function of a quarry should be interpreted as a set of elements, composed of escarpments, cliffs, spoil heaps, the stage of exploitation, etc. The paper discusses the impact of quarries on the landscape and their potential value for geotourism.
\end{abstract}

\section{Key words}

landscape • quarry $\cdot$ visualisation $\cdot$ geotourism $\cdot$ Poland

\section{Introduction}

This study is not concerned with the impact of quarrying on the natural or social environments, but rather with its impact on the landscape and its potential for geotourism. Can the impact of a quarry on the landscape be visually acceptable? In Poland there are approximately 730 quarries of medium and large size, which can have a potential impact on the landscape - the most attractive of them are in Table 1 and Figure 1.

For the purpose of this study landscape will be understood as the abiotic, biotic and anthropogenic environment inhabited by humans (Brzóska \& Żynda 1996). It is a highly complex, multidimensional and multifunctional system composed of mutually influencing and dependent geocomponents and their spatial units of various ranks known as geocomplexes or geosystems (Kondracki \& Richling, 1983). These geocomponents include the terrain morphology, soils, geology, hydrology, climate, plant life and animals (Kondracki 1980). The paper looks at quarries as such geocomplexes. In an abandoned quarry anthropogenic, biotic and abiotic components arrive at a certain equilibrium. A quarry, whether active or abandoned, constitutes a landscape structure, or has specific functions in such a structure, contributing such components as escarpments, cliffs, spoil banks, exploration levels, etc., but rarely all of them at the same time. A large quarry, which constitutes a self-contained unit, may in itself be regarded as a landscape, a quarry landscape.

The objective of this study is to draw attention to the role of quarries in the landscape and the changing approaches to their management after 
Table 1. Rock resources in Poland and their most attractive extraction sites.

\begin{tabular}{|c|c|c|}
\hline Quarry & Number & Example \\
\hline Sandstone & 237 & Szydłów, Barciszów, Barwałd, Śmiłów \\
\hline Limestone & 174 & Czatkowice, Bolechowice, Morawica, Wola Morawicka, Szczukowskie Górki, Strzelce Opolskie \\
\hline Granite & 64 & Strzegom, Strzelin, Chwałków, Kamienna Góra \\
\hline Basalt & 51 & Jawor-Męcinka, Kłopotno, Rutki, Wojciechów \\
\hline Dolomite & 46 & Brudzowice, Winna, Ząbkowice Będzińskie, Podleśna \\
\hline Marble & 24 & Kletno, Stronie Śląskie, Mielnik, Nowy Waliszów \\
\hline Melaphyre & 19 & Borówno, Regulice, Rybnica Leśna, Świerki \\
\hline Marl and gaize & 3 & Nikodemówka, Trawniki, Popów \\
\hline Porphyry & 12 & Boguszów-Gorce, Miękinia-Wschód, Zalas \\
\hline Gneiss & 10 & Doboszowice, Kamienna Góra, Mikoszów, Strzelin \\
\hline Syenite & 10 & Brodziszów, Przedborowa, Kośmin \\
\hline Quartz & 9 & Jędrzychowice, Krasków, Taczalin \\
\hline Marl & 9 & Nasiłów, Rejowiec, Groszowice, Dobrzeń \\
\hline Granodiorite & 8 & Łażany, Kluczowa, Rogówka \\
\hline Amphibolite & 7 & Kluczowa, Ogorzelec, Piława Górna, Gniewoszów \\
\hline Serpentinite & 6 & Jordanów Śląski, Nasławice, Sobótka \\
\hline Barite & 5 & Strawczynek, Boguszów, Jedlinka \\
\hline Chalcedonite & 4 & Teofilów, Dęborzyczka, Lubocz \\
\hline Gabbro & 4 & Braszowice, Dębówka, Ząbkowice Śląskie \\
\hline Glacial erratics & 4 & Wierzchowo, Bukowa Góra, Chlebowo \\
\hline Slate & 3 & Złoty Stok, Kapela \\
\hline Greystone & 3 & Jenków, Młynów, Dębowiec \\
\hline Flint & 2 & Tokarnia, Bocheniec \\
\hline Travertine & 2 & Zalesiaki \\
\hline Conglomerate & 2 & Berberysówka, Zygmuntówka \\
\hline Other & 12 & Niedźwiedzia Góra, Gozdnica, Dobrzechów \\
\hline Total & 730 & \\
\hline
\end{tabular}

Source: based on a Polish Geological Institute database - Midas.

decommissioning. The legal obligation to reinstate abandoned quarries has resulted in the ubiquitous, but often-dubious practice of reinstating them by filling them in and afforesting the site. The author highlights the fact that quarries that have not been reinstated tend to be more attractive to both nature and humans than before the quarry operation started.

The study uses information from generally available Polish Geological Institute databases on deposits and minerals, including, among others: Central Geological Database (http://geoportal.pgi.gov.pl/cbdg), Midas (http://geoportal.pgi. gov.pl/portal/page/portal/MIDASGIS/start) and Infogeoskarb (http://baza.pgi.gov.pl/igs/). Information was also sourced from various spatial information systems, topographic databases, the Geoportal (http://www.geoportal.gov.pl/en/), etc. These sources generally share a common deficiency, as they focus on selected criteria, such as deposits, and on the newest sites, mostly still operating. In doing so, they offer little or no archival data and information about the condition of abandoned quarries, let alone about landscape considerations. For these reasons the author also made his own field observations.

\section{Research topic - an outline}

Quarries involve various dynamic phenomena and processes, and are dominated by anthropogenic factors. This domination means that their area is 


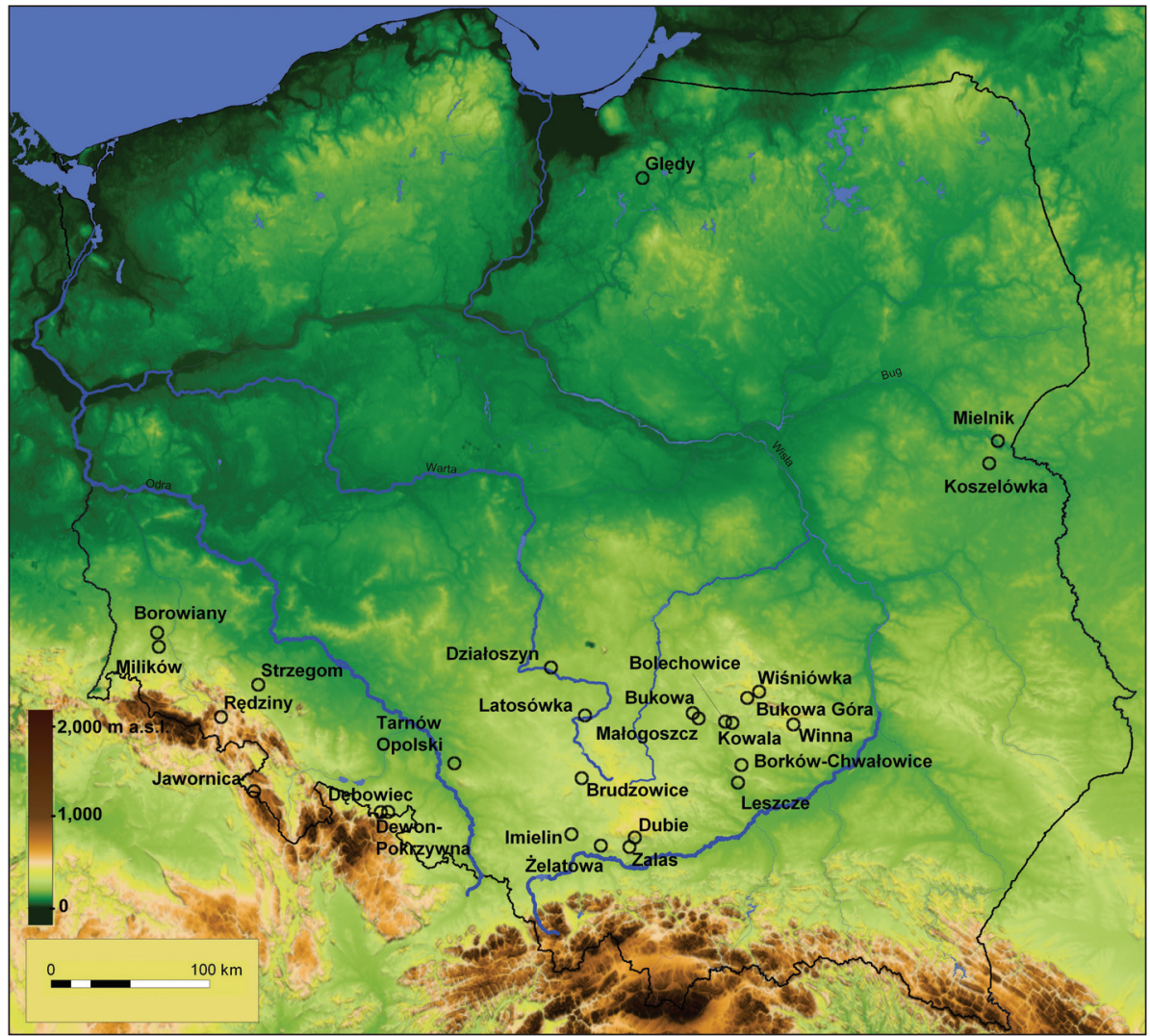

Figure 1. A sample of the Polish quarries selected for Table 1 set against a Digital Terrain Model and the river network. The DTM was constructed as part of an SRTM mission of the space shuttle Endeavour in February 2000; SRTM-3 corresponds to a 3" grid, i.e. $x=60 \mathrm{~m}, \mathrm{y}=90 \mathrm{~m}$ grid.

marked by a specific type of cultural landscape, i.e. the quarry landscape (Malewski 1999; Uberman 2001). For this reason quarries should not be perceived just in terms of degraded natural landscape, but as a new quality that takes little effort to become useful for certain purposes, such as geotourism (Kozłowski 1997; Kostrzewski 1998; Hüttl \& Gerwin 2003; Zwoliński 2004, 2010; Cañadas \& Ruiz-Flaño 2007). The most problematic period in the life of a quarry from a landscape perspective is the not during, but after its operation. A number of factors and functions determine the role, which is given to an abandoned quarry, including economic, social, environmental and legal (under regulations on the reinstatement of the former mineral working sites) (Alexandrowicz \& Urban 2003; Bromowicz 2005; Górecki \& Sermet 2010). There are numerous studies in various countries considering abandoned quarries as valuable sites for future landscape management and maintenance (Prosser et al. 2006; Storemyr
2006; Harrell \& Storemyr 2009). The dominant approach in these studies is from a conservationist or geochemical perspective, as the majority of authors focus on the actual or potential habitat conditions for specific plant life or wildlife (Hüttl \& Weber 2001; Morin \& Hutt 2001; Hancock et al. 2006; Conesa et al. 2007; Kuznetsova et al. 2010). The use of an abandoned quarry largely depends on the type of rock that was worked and on local demand. Various studies claim that sites that are abandoned and not reinstated can often be more attractive from the natural and human perspective (such as for tourism, geotourism, education and research) than they were before the quarry operation started. (Nita \& Myga-Piatek 2005, $2006 a, b)$. There are numerous recent examples of such sites being used for leisure, tourist and geotourist purposes in Poland, including at Kadzielnia, Bałtów, Krasiejów, Gródek, etc. Examples dating back nearly 100 years are found worldwide, including the Butchart Gardens limestone quarries 
on Vancouver Island, Canada. After the quarry exhausted its commercial deposits in 1904, magnificent botanic gardens were established on a 50-hectare site. Between March and October, more than one million plants belonging to approximately 700 varieties bloom, giving the old quarry a special atmosphere which attracts one million visitors every year (see: http://www.butchartgardens.com).

\section{The role of quarries in the landscape}

In considering the role of quarries the question must be asked: "What, indeed, is a quarry?" A quarry is a type of open cast extraction mine, whether in a mountainside or a pit in the ground. It is also an outcrop of usable assets, i.e. of compact rock ranging in hardness from medium to high (Mizerski \& Sylwestrzak 2002; Glapa \& Korzeniowski 2005). The principal method of extracting rock is through controlled explosions in the rock face. This method is limited to hard or medium hard rocks, while softer deposits, such as brown coal, fire clay, silt, etc., are worked using excavators and their mines are not classified as quarries. What separates quarries from other types of extraction pits (sand, gravel and clay pits), is their permanence and resistance to mass movements, such as rockfalls, landslides and soil creep, etc. Quarries can remain a landscape component for a much longer period of time.

Quarries are not just permanent, but also very distinct from the surrounding landscape when viewed from above, with oval, elongated, elliptical or irregular shapes, depending largely on the pattern of the deposit and the local morphology. Quarries can be compact or complicated in shape; they may be single features with small protrusions or be scattered as a series of inter-connected pits. They vary in depth; the deepest quarry in Poland is at Strzelin (104 m), while the copper mine Chuquicamata in Chile holds the world record for a quarry (more than $900 \mathrm{~m}$ ). Quarries can have several extraction levels, which are typically concentric and each lower level is smaller than the one above. Some quarries involve more than one type of rock, but this type is in decline and most quarries only extract one type of rock. In terms of assimilation in the landscape, quarries may be active or inactive and operated continuously or intermittently (operations being suspended during slumps in the market). Polish quarries mostly extract sandstone, limestone, granite, basalt, dolomite, marble, melaphyre, marl, porphyry, gneiss, syenite, diabase, quartzite, serpentinite and amphibolite. In terms of its landscape presence the most important morphological elements of a quarry include: steep cliffs, slopes (at the boundary between the excavated and non-excavated part of the rock), the quarry basin (left after the rock has been quarried), spoil banks or unusable rock, roads or transport levels (normally parts of the rock temporarily designated for transport purposes). Other important elements include the upper and lower boundaries of the quarry (conventional linear elements delimiting the quarry), quarry bottom (the lowest part of a quarry), ramps (slopes adapted for vehicle traffic to and from the site), basins and cavities filled with water (closed depressions gathering ground seepage or runoff water).

The greatest dynamic threats in quarries are associated with landslides and rockfalls from cliffs. Flooding with runoff or ground water is equally dangerous. Indeed, as operations are abandoned the quarry is no longer artificially drained and a rising ground-water table will gradually cause the pit to flood. This is also the simplest and most popular way of natural management which is selected whenever conditions are right. Vertical cliffs that constitute the most defining feature of a quarry quickly begin to weather and degrade. Their greatest value involves the exposure of geological and tectonic features of the rock formation, but natural degradation processes quickly mask the most interesting features making them difficult to distinguish among other elements of nature. The feature of a quarry that is most permanent in the landscape is the pit itself, which is a lasting element of the terrain morphology despite the gradual degradation of the quarry boundaries.

\section{The quarry as an element of landscape. Post-industrial landscape}

The term quarry landscape may be used when investigating the landscape vs. quarry relationship, where the quarry is a clearly defined area within its cliffs and contains various biotic and abiotic features. This approach to landscape is based on an analysis of various definitions of landscape, e.g.: "A landscape is a set of substances and phenomena existing within a certain area, which sets this 
area apart from another" (Pawłowski 1938: 118). "A landscape is a section of the geographic space and a spatially limited subsystem of the epigeosphere" (Wojciechowski 1986: 143). In the case of a quarry this spatial limitation is very strong. Also Ciołek (1964: 32) uses a similar approach to space: "A landscape is an external manifestation of natural components existing in a naturally limited area", which again corresponds very well with the quarry. A quarry landscape is a "reality of nature that is a concrete manifestation of the geosphere. It means a relationship of phenomena on the earth's surface representing the essence of geographical objects" to quote Neef (1967: 120) whose definition again fits the reality of a quarry. Just as does "a landscape is a spatial system, composed of biotic, abiotic and anthropogenic elements" (Brzóska \& Żynda 1996: 115). There are many more similarities between general definitions of a landscape and that of a quarry landscape.

Quarries are common in the landscapes of central and southern Poland, even if their intrusion in the physical space is seldom accepted. Quarries are also often found in areas of outstanding natural qualities (Urban 1990; Urban \& Wróblewski 2004; Świercz \& Strzyż 2009). A common problem with quarries is how to manage the large areas of abandoned operations that they contain. It is widely held that quarries are detrimental to the natural environment due to their distortion of water balance, change in the morphology, destruction of the pedosphere, creation of spoil banks, changes to the landscape, etc. (Nita \& Myga-Piątek 2006a; Świercz \& Strzyż 2009), but also due to the fact that they add to the overall area of unused land and create a visual and aesthetic dissonance in the landscape (Pietrzyk-Sokulska 2003; Stawicki 2003).

On the other hand, the transformed surfaces resulting from the existence of a quarry may be considered as an opportunity. Many quarries feature interesting geological outcrops which may become geotourist attractions, especially if they are located in a previously monotonous landscape (Nita \& Myga-Piątek 2006a, b; Świercz \& Strzyż 2009). Often, with the passage of time, quarries blend with features of the surrounding landscape adding to its tourist, cultural, utility and biotic value (Kozioł et al. 2003; Alexandrowicz 2006; Nita \& Myga-Piątek 2005, 2006a). In recognition of these possibilities, the most typical existing approach to reinstatement, which involves the filling in of the pit and afforestation, has been increasingly replaced by a deliberate use of quarries as geotourist attractions, or even as permanent landscape features. It is paradoxical that the best results in the integration of quarries in the landscape are achieved through avoiding any reinstatement or management measures (Pietrzyk-Sokulska 2003; Wróblewski 2007; Nita \& Myga-Piątek 2006a; Myga-Piątek \& Nita 2008). Indeed, the component parts of a quarry assimilate gradually with the surroundings and even lend them unique beauty. There are numerous quarries that fulfil important scientific, educational, tourist and leisure functions (Wróblewski 2000; Nita \& Myga-Piątek 2006a; Świercz \& Strzyż 2009).

\section{Geotourist value of quarries}

A quarry can be useful for geotourism if it fulfils at least one of the following functions: scientific (paleontological, mineralogical or lithological finds), educational (clear geological profiles, tectonic or other geological features, etc.), evocative (well exposed typical quarry features, such as cliffs, spoil heaps, etc.), practical (easy access), tourist (interesting vantage points, water reservoirs, walking paths, rock-climbing sites, caves, etc.) and leisure (safe and managed leisure sites, jogging paths, car parks, etc.). With the use of these basic functions it is possible to develop or exhibit additional features to increase the quarry's attractiveness, but that require investment, such as walking or cycling paths, exhibits and exhibitions, additional structures, such as amphitheatres, etc.).

Perfect examples of quarries that build the natural-cultural landscape are found in a broad area of the Świętokrzyskie Mountains in south-central Poland. There are several abandoned quarries (the Zygmuntówka and Panek marble quarries) and other former extraction operations that constitute the Chęciny Landscape Park (Wróblewski 2000; Urban \& Wróblewski 2004; Nita \& Myga-Piątek 2006b; Świercz \& Strzyż 2009). One of the Park's objectives is to protect abiotic nature (geological features in eight geological reserves) and cultural features in harmony with the landscape. This task is not made easier by the existence of many operational quarries in the area (e.g. Jaźwica, Trzuskawica and Kowala). Other examples of a considerable contribution of quarries to the landscape include the historic quarries in Bałtów and Podole, which 
constitute together what is known as the "Dolina Kamienna" Geopark, and a Neolithic area of striped flint extraction in Krzemionki Opatowskie (Pieńkowski 2004). Throughout the region there are numerous examples of various approaches to the integration of abandoned quarries in the landscape, ranging from finished multifunctional projects (e.g. the Kadzielnia reserve), to partial or abandoned projects (the Wietrznia and Ślichowice reserves), to quarries that are left abandoned without any management plans (e.g. Zygmuntówka, Leśna Góra and other quarries). Any reinstatement or management measures should be intended to integrate the quarries into the landscape in a way that adds value, thus improving their geotourist attractiveness (Alexandrowicz 2006; Nita \& Myga-Piątek 2006b; Świercz \& Strzyż 2009). Places such as Krasiejów and Bałtów provide examples.

\section{Conclusions}

The study has shown that there are numerous ways to seamlessly combine the functions of an abandoned quarry with the surrounding landscape. A number of quarries in the region of the Świętokrzyskie Mountains provide examples of successful adaptation for leisure and tourism, while considerably improving the visual attractiveness of the landscape (Nita \& Myga-Piatek 2006b; Wróblewski 2000, 2007; Świercz \& Strzyż 2009).

\section{References}

Alexandrowicz Z., 2006. Geoparki - nowe wyzwanie dla ochrony dziedzictwa geologicznego. Przegląd Geologiczny, vol. 54, no. 1, pp. 36-41.

Alexandrowicz Z., Alexandrowicz S., 2004. Geoparks - the most valuable landscape parks in southern Poland [in:] A. Ber, Z. Alexandrowicz, P. Balabanis (eds.), Proceedings of the Conference "Geological heritage concept, conservation and protection policy in Central Europe", October 3-4, 2003, Cracow, Poland, Polish Geological Institute Special Papers, vol. 13, pp. 49-56.

AleXANDRowicz Z., Urban J., 2003. Zagospodarowanie kamieniołomów dla ochrony dziedzictwa geologicznego - projekty i ich realizacja [in:] J. Środulska-Wielgus, K. Wielgus, R. Panek (eds.), Kształtowanie krajobrazu
There, however, remain a considerable number of quarries that are left without management, decaying and sometimes converted into waste dumps. These sites, if properly managed, could play an important role, for example in geotourism, thus improving the region's tourist and leisure attractiveness (Alexandrowicz \& Alexandrowicz 2004; Alexandrowicz 2006; Nita \& Myga-Piątek 2006b). Quarries can be converted at a relatively small expense for the purposes of tourism and leisure (general leisure, fishing grounds, skiing slopes, cycling and walking paths, campsites, amphitheatres, exhibition sites, etc.), sports (football grounds, rock-climbing walls, golf courses, etc.), educational (educational trails, educational centres, wildlife reserves), research (documentation sites, geological profiles, etc.). This would require a change in the entrenched approach linked to the closing of quarrying operations and requiring obligatory reinstatement. Each quarry should be approached on a case-by-case base and the local authorities should have the right to decide how a quarry should be utilised. This could be achieved with a local masterplan taking into account the requirements of safety, landscape conservation, the expectations of the local communities and economic criteria.

Editors' note:

Unless otherwise stated, the sources of tables and figures are the author(s), on the basis of their own research. terenów poeksploatacyjnych w górnictwie, Kraków: Akademia Górniczo-Hutnicza, Politechnika Krakowska, pp. 193-195.

BRomowicz J. (ED.), 2005. Waloryzacja polskich złóż kamieni budowlanych i drogowych na tle przepisów Unii Europejskiej. Kraków: Uczelniane Wydawnictwa Naukowo-Dydaktyczne AGH, 113 pp.

BRzósKA J., ŻYNDA S., 1996. Struktura przestrzenno-funkcjonalna systemu przyrodniczego - część abiotyczna na przykładzie wybranych obszarów Wielkopolskiego Parku Narodowego i jego otuliny [in:] M. Kistowski (ed.), Badania ekologiczno-krajobrazowe na obszarach chronionych, Problemy Ekologii Krajobrazu, vol. 2, pp. 112-118.

Cañadas S.E., Ruiz-Flaño P., 2007. Geodiversity: concept, assessment and territorial application. The case 
of Tiermes-Caracena (Soria). Boletín de la Asociación de Geógrafos Españoles, no. 45, pp. 389-393.

ClOŁEK G., 1964. Zarys ochrony i kształtowania krajobrazu. Warszawa: Arkady, 55 pp.

Conesa H.M., García G., Faz A., Arnaldos R., 2007. Dynamics of metal tolerant plant communities' development in mine tailings from the Cartagena-La Unión Mining District (SE Spain) and their interest for further revegetation purposes. Chemosphere, vol. 68, no. 6, pp. 1180-1185.

Glapa W., KorzenIowsKı J.I., 2005. Mały leksykon górnictwa odkrywkowego. Wrocław: Wydawnictwa i Szkolenia Górnicze Burnat \& Korzeniowski, 139 pp.

Górecki J., Sermet E., 2010. Kamieniołomy Krakowa dziedzictwo niedocenione [in:] P.P. Zagożdżon, M. Madziarz (eds.), Dzieje górnictwa - element europejskiego dziedzictwa kultury, vol. 3, Wrocław: Oficyna Wydawnicza Politechniki Wrocławskiej, pp. 123-138.

Hancock G.R., Grabham M.K., Martin P., Evans K.G., BollhöFER A., 2006. A methodology for the assessment of rehabilitation success of post mining landscapes - sediment and radionuclide transport at the former Nabarlek uranium mine, Northern Territory, Australia. Science of the Total Environment, vol. 354, iss. 2-3, pp. 103-119.

Harrell J.A., Storemyr P., 2009. Ancient Egyptian quarries - an illustrated overview [in:] N. Abu-Jaber, E.G. Bloxam, P. Degryse, T. Heldal (eds.), QuarryScapes: ancient stone quarry landscapes in the Eastern Mediterranean, Geological Survey of Norway Special Publication, 12, pp. 7-50.

HütTL R.F., GERWIN W., 2003. Rehabilitation of post-mining landscapes - the lignite mining district of lower Lusatia, Germany [in:] J. Środulska-Wielgus, K. Wielgus, R. Panek (eds.), Kształtowanie krajobrazu terenów poeksploatacyjnych w górnictwie, Kraków: Akademia Górniczo-Hutnicza, Politechnika Krakowska, pp. 232-243.

HüttL R.F., WeBer E., 2001. Forest ecosystem development in post-mining landscapes: a case study of the Lusatian lignite district. Naturwissenschaften, vol. 88, iss. 8, pp. 322-329.

KondRACKI J., 1980. Geografia fizyczna Polski. Warszawa: Państwowe Wydawnictwo Naukowe, 463 pp.

KondRACKI J., Richling A., 1983. Próba uporzadkowania terminologii w zakresie geografii fizycznej kompleksowej. Przeglad Geograficzny, vol. 55, no. 1, pp. 201-217.

KostrzeWSKI A., 1998. Georóżnorodność rzeźby jako przedmiot badan geomorfologii [in:] K. Pękala (ed.), IV Zjazd Geomorfologów Polskich. Główne kierunki badań geomorfologicznych w Polsce. Stan aktualny i perspektywy, Lublin: Wydawnictwo UMCS, pp. 11-16.
Koziot W., Kawalec P., Chudzik W., 2003. Koncepcje zagospodarowania wyrobiska kopalni zlepieńca "Zygmuntówka" [in:] J. Środulska-Wielgus, K. Wielgus, R. Panek (ed.), Kształtowanie krajobrazu terenów poeksploatacyjnych w górnictwie, Kraków: Akademia Górniczo-Hutnicza, Politechnika Krakowska, pp. 318-330.

KozŁowski S., 1997. Prognoza ochrony georóżnorodności w Polsce. Przegląd Geologiczny, vol. 45, no. 5, pp. 489-496.

Kuznetsova T., Mandre M., Klôšeiko J., PÄrn H., 2010. A comparison of the growth of Scots pine (Pinus sylvestris L.) in a reclaimed oil shale post-mining area and in a Calluna site in Estonia. Environmental Monitoring and Assessment, vol. 166, iss. 1-4, pp. 257-265.

MALEWSKI J. (ED.), 1999. Zagospodarowanie wyrobisk. Technologiczne, przyrodnicze i gospodarcze uwarunkowania zagospodarowania wyrobisk poeksploatacyjnych surowców skalnych Dolnego Ślaska. Wrocław: Oficyna Wydawnicza Politechniki Wrocławskiej, 225 pp.

Mizerski W., Sylwestrzak H., 2002. Słownik geologiczny. Warszawa: Wydawnictwo Naukowe PWN, $242 \mathrm{pp}$.

Morin K.A., Hutt N.M., 2001. Relocation of net-acid-generating waste to improve post-mining water chemistry. Waste Management, vol. 21, iss. 2, pp. 185-190.

Myga-Piatek U., Nita J., 2008. The scenic value of abandoned mining areas in Poland. Acta Geographica Debrecina Landscape \& Environment Series, vol. 2, iss. 2, pp. 132-142.

NeEf E., 1967. Die theoretischen Grundlagen der Landschaftslehre. Gotha-Leipzig: VEB Hermann Haack, $152 \mathrm{pp}$.

Nita J., Myga-Piątek U., 2005. Poszukiwanie możliwości zagospodarowania obszarów poeksploatacyjnych w celu zachowania ich walorów geologicznych $i$ krajobrazowych. Technika Poszukiwań Geologicznych. Geosynoptyka i Geotermia, vol. 44, no. 3, pp. 53-72.

Nita J., Myga-Piatek U., 2006a. Krajobrazowe kierunki zagospodarowania terenów pogórniczych. Przegląd Geologiczny, vol. 54, no. 3, pp. 256-262.

Nita J., Myga-Piątek U., 2006b. O potrzebie ochrony wyrobisk górniczych dla podniesienia walorów krajobrazowych i celów dydaktycznych obszarów eksploatacji surowców skalnych na przykładzie regionu Kielecko-Chęcińskiego. Technika Poszukiwań Geologicznych, Geotermia, Zrównoważony Rozwój, vol. 45, no. 1, pp. 47-56.

PAWŁoWski S., 1938. Geografia jako nauka i przedmiot nauczania. Lwów-Warszawa: Książnica-Atlas, $215 \mathrm{pp}$. 
PieńKowski G., 2004. Nowy geopark „Dolina Kamiennej". Wiadomości PIG, no. 11 (164), pp. 1-2.

PietrzYk-SOKUlSKa E., 2003. Kamieniołomy surowców skalnych w polskim krajobrazie [in:] J. Środulska-Wielgus, K. Wielgus, R. Panek (ed.), Kształtowanie krajobrazu terenów poeksploatacyjnych w górnictwie, Kraków: Akademia Górniczo-Hutnicza, Politechnika Krakowska, pp. 43-53.

Prosser C., Murphy M., Larwood J., 2006. Geological conservation: a guide to good practice, Peterborough: English Nature, 145 pp.

StawiCKI H., 2003. Kształtowanie krajobrazu wyrobisk poeksploatacyjnych w górnictwie skalnym [in:] J. Środulska-Wielgus, K. Wielgus, R. Panek (ed.), Kształtowanie krajobrazu terenów poeksploatacyjnych w górnictwie, Kraków: Akademia Górniczo-Hutnicza, Politechnika Krakowska, pp. 25-43.

StOREMYR P., 2006. Reflections on conservation and promotion of ancient quarries and quarry landscapes [in:] P. Degryse (ed.), Conservation of ancient stone quarry landscapes in the Eastern Mediterranean. Proceedings to the first QuarryScapes symposium, October 15-17 2006, Antalya, Turkey, pp. 31-36.

Świercz A., StrzYż M., 2009. Rewitalizacja terenów poeksploatacyjnych na przykładzie regionu świętokrzyskiego [in:] S. Bródka, I. Markuszewska (eds.), Problemy środowiska przyrodniczego terenów poprzemysłowych, Problemy Ekologii Krajobrazu, vol. 24. pp. 59-70.

UBERMAN R., 2001. Kierunki zagospodarowania odkrywkowych wyrobisk poeksploatacyjnych w aglomeracji krakowskiej. Górnictwo Odkrywkowe, vol. 43, no. 4, pp. 17-26.

URBAN J., 1990. Ochrona obiektów przyrody nieożywionej w Krainie Gór Świętokrzyskich. Rocznik Świętokrzyski, vol. 17, pp. 47-79.

Urban J., WróbleWski T., 2004. Chęciny-Kielce Landscape Park - an example of officially not proclaimed geopark [in:] A. Ber, Z. Alexandrowicz, P. Balabanis (eds.), Proceedings of the Conference "Geological heritage concept, conservation and protection policy in Central Europe", October 3-4, 2003, Cracow, Poland, Polish Geological Institute Special Papers, vol. 13, pp. 131-136.

WoJCIECHOWski K.H., 1986. Problemy percepcji i oceny estetycznej krajobrazu. Rozprawy Wydziału Biologii i Nauk o Ziemi, vol. 28, Lublin: Uniwersytet Marii Curie-Skłodowskiej, 283 pp.

WRÓBLEWSKI T., 2000. Ochrona georóżnorodności w regionie świętokrzyskim. Warszawa: Państwowy Instytut Geologiczny, 88 pp.

WRÓBLEWSKI T. (ED.), 2007. Obiekty przyrody nieożywionej w kieleckim obszarze metropolitalnym objęte programem Geopark Kielce-Plus. Kielce: Apla, 60 pp.

ZwOLINSKI Z., 2004. Geodiversity [in:] A.S. Goudie (ed.), Encyclopedia of Geomorphology. Vol. 1, A-I, London: Routledge, pp. 417-418.

ZWOLIŃSKI Z., 2010. Aspekty turystyczne georóżnorodności rzeźby Karpat [in:] W. Andrejczuk (ed.), Krajobraz a turystyka, Prace Komisji Krajobrazu Kulturowego, 14, pp. 316-327. 